Doctrinal Structure of Enablement - DRAFT

Jason Rantanen

$8 / 9 / 16$

\title{
The Doctrinal Structure of Patent Law's Enablement Requirement
}

\author{
Jason Rantanen ${ }^{1}$
}

\begin{abstract}
This Essay examines the formal law of enablement, focusing on a perceived split in the enablement doctrine: whether disclosure of a single mode of an invention is necessarily sufficient to satisfy the requirement of enablement or whether the full scope of the claim must be enabled. In examining this split, this Essay articulates the enablement inquiry in conceptual terms, identifying two elements of the courts' analyses that are implicit in every enablement determination: the nature of enablement disputes as challenges and the articulation of a target or targets that must be enabled. With this understanding in mind, the "full scope" and "any mode" language are easily reconciled: for any given target, one mode suffices. But each and every target must be enabled. More broadly, recognizing the process of target articulation implicit in every enablement inquiry leads to a conceptually simpler, and more generalizeable, understanding of how the requirement operates in practice.
\end{abstract}

Introduction $\quad 1$

$\begin{array}{ll}\text { I. Precedent and the Split } & \mathbf{7}\end{array}$

A. Working backwards from Automotive Technologies and Johns Hopkins 7

1. Engel Industries and the one-mode language $\quad 7$

2. Automotive Technologies and the "full scope" language 9

B. Working forwards from Tilghman and The Incandescent Lamp Case 11

C. The CCPA and "Commensurate"

II. Implicit Doctrine and the Enablement Requirement 19

A. On the Nature of Legal Doctrine 19

$B$. The form of legal disputes over enablement 24

C. The determinative nature of target articulation $\quad 25$

III. The characteristics of a valid target

$\begin{array}{ll}\text { Conclusion } & 34\end{array}$

INTRODUCTION

\footnotetext{
${ }^{1}$ Professor of Law, University of Iowa College of Law. Thanks to the participants in the Vanderbilt Law Review Symposium on Patent Disclosure, as well as Jeffrey Lefstin, June T. Tai, Oskar Liivak, Dmitry Karshtedt, Lisa Larrimore Ouellette, and Jonas Anderson. Thanks as well to my research assistants Briana Chamberlin, Andrew Stanley, Peter Kline, and Carmen Christensen.
} 
Patent law's enablement requirement rests on a two-century-old statutory foundation that in order to obtain a patent, an inventor shall deliver "a specification in writing....which specification shall be so particular...[as] to enable a workman or other person skilled in the art or manufacture, whereof it is a branch, or wherewith it may be nearest connected, to make, construct or use the same...."2 The enablement requirement is a fundamental component of the patent law quid pro quo: in return for a patent, an inventor must disclose sufficient information about the invention. ${ }^{3}$

Despite its statutory foundation, much of the actual doctrine of enablement takes the form of statements in judicial opinions. The statutory language, although containing some key concepts, is relatively brief, ${ }^{4}$ and it is judicial interpretation and application of the statute that has produced what

2 Patent Act of 1790 . The full text of this provision is:

And be it further enacted, That the grantee or grantees of each patent shall, at the time of granting the same, deliver to the Secretary of State a specification in writing, containing a description, accompanied with drafts or models, and explanations and models (if the nature of the invention or discovery will admit of a model) of the thing or things, by him or them invented or discovered, and described as aforesaid, in the said patents; which specification shall be so particular, and said models so exact, as not only to distinguish the invention or discovery from other things before known and used, but also to enable a workman or other person skilled in the art or manufacture, whereof it is a branch, or wherewith it may be nearest connected, to make, construct, or use the same, to the end that the public may have the full benefit thereof, after the expiration of the patent term; which specification shall be filed in the office of the said Secretary, and certified copies thereof, shall be competent evidence in all courts and before all jurisdictions, where any matter or thing, touching or concerning such patent, right, or privilege, shall come in question.

Subsequent versions of the patent law are similar, continuing to use the terms "enable," "person skilled in the art," and "make" and "use," but with some variations. See CHISUM ON PATENTS, § 7.02 (recounting the historical development of the disclosure requirement). 3 See Jason Rantanen, Patent Law's Disclosure Requirement, 45 LoY. U. CHI. L.J. 369 (2013). But see Mark A. Lemley, The Myth of the Sole Inventor, 110 MicH. L. REV. 709, 745 (2012) (arguing that "Disclosure theory cannot, however, support the modern patent system); J. Jonas Anderson, Secret Inventions, 26 BERK. TECH. L. J. 917 (2011) (analyzing the situations in which the disclosure function operates and suggesting changes to encourage the use of secrecy by inventors where appropriate). For a discussion of why enablement might matter even irrespective of whether disclosure theory actually supports the patent system, see Lisa Larrimore Oullette, Do Patents Disclose Useful Information?, 25 HARV. J.L. \& TECH. 545 (2012).

4 The modern incarnation of the statute, 35 U.S.C. $\S 112(\mathrm{a})$, simply states that "The specification shall contain a written description of the invention, and of the manner and process of making and using it, in such full, clear, concise, and exact terms as to enable any person skilled in the art to which it pertains, or with which it is most nearly connected, to make and use the same...." 
can be called the enablement doctrine. Judicial pronouncements about enablement law thus operate as a critical layer of formal doctrine, and are as important (if not more so in practice) than the statutory language itself.

Within this layer of express judicial statements exists a well-recognized split: whether enablement of a single mode or embodiment of the claimed invention is sufficient, or whether the full scope of the claim must be enabled. ${ }^{5}$ One line of Federal Circuit cases contains variations on the theme that " $[t]$ he enablement requirement is met if the description enables any mode of making and using the invention." 6 This language does not say that disclosure of one mode can or may be sufficient to enable the claims. It says that one mode necessarily enables the claims: the enablement requirement "is met" if the description enables any mode of making and using the invention. The outcomes of these cases leave no doubt that one is sufficient. ${ }^{7}$

Another line of cases says the opposite:

We [] reject ATI's argument that because the specification enables one mode of practicing the invention, viz., mechanical side impact sensors, the enablement requirement is satisfied. We addressed and rejected a similar argument made in LiebelFlarsheim Co. v. Medrad, Inc. .... Thus, in order to fulfill the

5 In patent law, "embodiment" and "mode" are terms that everyone uses but no one seems to define. See, e.g., CHISUM, supra note 2, Glossary Patent Terms (containing no entries for "embodiment" or "mode.") Alan J. Kasper et. al., PATENTS AFTER THE AIA: EVolving LAW AND PRACTice (2016) (same); Janice M. Mueller, PATENT LAW, Third Edition (2009) (same). Roughly speaking, an "embodiment" in patent law is a particular version of an invention and "mode" in general legal terms means "the manner in which a thing is done." BLACK'S LAW DICTIONARY. The two terms are sometimes used synonymously, and the caselaw does not indicate a clear distinction between the two other than, as Timothy Saulsbury observed, the term "embodiment" has never been used to articulate the rule that a single [embodiment/mode] is sufficient. Timothy Chen Saulsbury, Pioneers Versus Improvers: Enabling Optimal Patent Claim Scope, 16 Mich. Telecomm. \& TECH. L. REV. 439, 460-61 (2010). Indeed, part of what drives the explanation offered in this Essay is the imprecision in and lack of collective meaning for these terms. For a deep dive into the conceptual issues associated with the embodiment concept itself, see Tun-Jen Chiang, The Levels of Abstraction Problem in Patent Law, 105 Nw. U. L. REV. 1097 (2011).

${ }^{6}$ See Johns Hopkins Univ. v. CellPro, Inc., 152 F.3d 1342, 1361 (Fed. Cir. 1998) (quoting Engel Indus., Inc. v. Lockformer Co., 946 F.2d 1528, 1533 (Fed. Cir. 1991)); see also Amgen Inc. v. Hoechst Marion Roussel, Inc., 314 F.3d 1313, 1338-39 (Fed. Cir. 2003); Edwards Lifesciences AG v. CoreValve, Inc., 699 F.3d 1305, 1309 (Fed. Cir.

2012). These cases do not give any special distinguishing meaning to "mode" versus "embodiment," often stating the rule in "mode" language before switching to references to embodiments.

${ }^{7}$ See Johns Hopkins, 152 F.3d at 1359 (holding claim to genus of antibodies enabled by disclosure of one cell line); Edwards, 699 F.3d at 1309 (affirming jury instruction stating that the enablement requirement is met if the description enabled "any mode of making and using the invention."). 
enablement requirement, the specification must enable the full scope of the claims that includes both electronic and mechanical side impact sensors, which the specification fails to do. ${ }^{8}$

These two pronouncements stand in direct contradiction. The first says that enablement of one mode is enough, the other that it is definitely not enough.

Citation patterns reinforce the appearance of a split, with some opinions citing only to cases in the full-scope line and others only to cases in the onemode line. Notwithstanding Liebel-Flarsheim and Automotive Technologies, recent Federal Circuit and district court opinions cite Johns Hopkins v. Cellpro for its "any mode" language: "It is well established that the "enablement requirement is met if the description enables any mode of making and using the invention." 9 Other recent cases cite Automotive Technologies for the requirement that "[t]he full scope of the claimed invention must be enabled."10

Given this apparent contradiction, it's hardly surprising that scholars (and litigants) recognize it. In the wake of Liebel-Flarsheim ${ }^{11}$ and Automotive Technologies, ${ }^{12}$ Bernard Chao wrote:

"These decisions rely upon and then extend principles developed in one line of enablement decisions. They ignore, however, another line of cases that has evolved separately. This second line of cases simplified the enablement standard so that a specification that enables any embodiment satisfies the enablement requirement notwithstanding the breadth of the claims. Liebel-Flarsheim, Automotive Technologies, and

\footnotetext{
${ }^{8}$ Auto. Techs. Int'l, Inc. v. BMW of N. Am., Inc., 501 F.3d 1274, 1285 (Fed. Cir. 2007). See also ALZA Corp. v. Andrx Pharms., LLC, 603 F.3d 935, 943 (Fed. Cir. 2010) (holding full scope of claims not enabled when osmotic, but not non-osmotic, method of medication delivery was enabled); Sitrick v. Dreamworks, LLC, 516 F.3d 993, 999 (Fed. Cir. 2008) (holding enablement of claim in games insufficient when movies also fell within claim's scope).

9 Takeda Pharm. Co. Ltd. v. Zydus Pharm. USA, Inc., 743 F.3d 1359, 1369 (Fed. Cir. 2014) (quoting Johns Hopkins Univ. v. CellPro, Inc., 152 F.3d 1342, 1361 (Fed. Cir.1998) (emphasis added by court)); see also Abbott Biotechnology Ltd. v. Centocor Ortho Biotech, Inc., 35 F. Supp. 3d 163, 180 (D. Mass. 2014) (holding disclosure of one method of manufacturing a drug sufficient for enablement); Johnson \& Johnson Vision Care, Inc. v. CIBA Vison Corp., 648 F. Supp. 2d 1294, 1342 (M.D. Fla. 2009) (holding that the disclosure of one method of creating claimed contact lens was sufficient for enablement).

10 Sitrick 516 F.3d at 999.

11 Liebel-Flarsheim Co. v. Medrad, Inc., 481 F.3d 1371 (Fed. Cir. 2007).

${ }^{12}$ Auto. Techs., 501 F.3d at 1274. 
Doctrinal Structure of Enablement - DRAFT

Jason Rantanen

$8 / 9 / 16$

Sitrick take the existing split in Federal Circuit law and pry it even further open."13

Other commentary is in the same vein. ${ }^{14}$ Tun-Jen Chiang observed that "[e]nablement and written description therefore contain two directly contradictory lines of cases. One line holds that every claimed embodiment must be disclosed by the specification, an impossible requirement that renders every patent either invalid or completely worthless. The other line holds that a single working embodiment enables everything, which places no limit whatsoever on patent scope." 15 Kevin Collins wrote about the split in the context of after-arising technology ("AAT"): "the Federal Circuit's cases addressing the enablement of claims encompassing AAT are commonly viewed as inconsistent and chaotic. Grossly characterized, they contain three irreconcilable variations on the commensurability requirement, each of which has a different implication for the reach of enabled claims into AAT."16

$* * *$

This Essay challenges the entrenched view of a split in the enablement doctrine. Instead, this Essay argues, what appears as a "split" in the express, formal law of enablement is really the operation of another, unseen layer of the law: implicit doctrine. Implicit doctrine, as defined in Part II, constitutes those components and steps of legal analysis that are inherent or necessary to determining the resolution of a legal outcome but which are not formally articulated in the court's express doctrine.

Implicit doctrine plays a critical role in the resolution of questions about whether a patent claim is enabled. Implicit in courts' analyses of enablement

${ }^{13}$ Bernard Chao, Rethinking Enablement in the Predictable Arts: Fully Scoping the New Rule, 2009 STAN. TECH. L. REV. 3, 7.

${ }^{14}$ See generally J. Benjamin Bai, Enablement Issues Concerning Aggressively Broad Generic Claims, 7 Nw. J. TECH. \& INTELL. Prop. 1 (2008); Timothy Chen Saulsbury, Pioneers Versus Improvers: Enabling Optimal Patent Claim Scope, 16 Mich. TELEComm. \& TECH. L. Rev. 439 (2010); Sean B. Seymore, The Enablement Pendulum Swings Back, 6 NW. J. TECH. \& INTELL. PROP. 278 (2008).

15 Tun-Jen Chiang, Fixing Patent Boundaries, 108 MiCH. L. REv. 523, 537-38 (2010); see also Chiang, supra note 5, at 1116-17.

16 Kevin Emerson Collins, Enabling After-Arising Technology, 34 J. CoRP. L. 1083, 108788 (2009) (identifying the "full scope," "single embodiment," and "reasonableness" lines of enablement cases); cf. Saulsbury, supra note 5, at 454 (describing the different articulations of the enablement requirement as "seemingly inconsistent standards"). As discussed infra in note 127, Saulsbury ultimately offers a partial solution as applied to the making of inventions claimed in product terms and which invokes the concepts of "thing construction" and "intrinsic" and "extrinsic" properties. This Essay recognizes Saulsbury's insights, but offers a more generalizable explanation for the cases that, I hope, is presented in relatively easy to understand terms. 
are two components, one inherent and the other necessary. First, determinations of enablement always take the form of a challenge. There is no positive obligation to demonstrate the enablement of a claim. ${ }^{17}$ The enablement issue only arises once a challenge has been issued; a particular gauntlet thrown.

The structure of enablement as a challenge leads to the second implicit component of enablement determinations: the articulation of a target that must be enabled, a necessary step in any enablement analysis. As part of a challenge to enablement, the challenger must identify a target that the patent allegedly fails to satisfy through its disclosure. Sometimes the target is singular; other times, the targets are multiple. As long as the patent owner can demonstrate that the disclosure allows a person of ordinary skill in the art to make and use the target in at least one way (without undue experimentation), the enablement challenge is won. But where there are multiple targets specified, the challenge presented by each of those targets must be met.

Seen in this way, what seems to be a split is not. What matters for purposes of the enablement inquiry is the how the target is articulated rather than the choice of the one mode/full scope line of precedent. Both are correct. One mode means that any given target must be enabled by only a single mode; full scope means that every target must be enabled, each by a single mode.

Of course, challengers may not articulate just anything as a target. There are limits on what courts (and importantly, the Federal Circuit) will find acceptable. Obviously, there must be some connection to the claims-but enablement does not always involve claim construction as that concept is understood today. This Essay does not attempt to offer a definitive guide on target articulation. Instead, its purpose is to describe the implicit components of the enablement doctrine. Nevertheless, in the aim of advancing our understanding of enablement doctrine, it suggests some characteristics of valid and invalid targets that courts have looked at. ${ }^{18}$

Part I describes the history of the one mode/full scope split, a history that turns out to be more complex than previously recognized in the literature. Part II explains the concept of implicit doctrine and its role in enablement determinations - in particular, the nature of enablement determinations as challenges and the role of target articulation in the enablement inquiry. Part III discusses characteristics of valid and invalid targets, concluding with a

${ }^{17}$ Cf. Sean B. Seymore, The Presumption of Patentability, 97 MinN. L. REV. 990, 997 (2013) ("The basic tenet of patent examination is that an applicant is entitled to a patent unless the Patent Office can prove otherwise.").

18 This Essay frames its discussion in the context of an apparent doctrinal split in the enablement doctrine, and thus focuses primarily on enablement. But aside from the specific discussion of the apparent one mode/full scope split, its description of the target process applies equally, I think, to written description analyses under $\S 112$, which focus more on the question of possession rather than the making and using of the invention. 
Doctrinal Structure of Enablement - DRAFT

Jason Rantanen

$8 / 9 / 16$

recommendation that courts make explicit the process of target articulation for purposes of the enablement inquiry.

\section{PRECEDEnT AND the Split}

\section{A. Working backwards from Automotive Technologies and Johns Hopkins}

The enablement doctrine finds its living, breathing existence in judicial pronouncements about the disclosure a patent must provide. Thus to understand the nature of the one mode/full scope split, we should begin with these pronouncements. And since judicial pronouncements ought be grounded as much as possible in precedent, a logical approach to studying the split is to work backwards, beginning with recent opinions and trekking back through those opinions' articulation of, and support cited for, the relevant legal statements.

\section{Engel Industries and the one-mode language}

Although the analysis could begin with later cases that cite the Federal Circuit's 1991 Engel Industries decision, that case marks a reasonable place to begin as previous scholarship has identified Engel as a starting point for a "one mode" line of precedent. ${ }^{19}$ Engel states simply that " $[\mathrm{t}]$ he enablement requirement is met if the description enables any mode of making and using the invention." 20 For this proposition, it cites a Federal Circuit decision from the previous year, Chemcast v. Arco Industries.

The appeal in Chemcast did not actually involve an enablement question; instead, the court addressed enablement only in the context of explaining the best mode requirement. ${ }^{21}$ In response to the patent owner's argument about the best mode requirement, the court stated that "This argument confuses best mode and enablement. A patent applicant must disclose the best mode of carrying out his claimed invention, not merely $a$ mode of making and using what is claimed. A specification can be enabling yet fail to disclose an applicant's contemplated best mode. See Spectra-Physics, 827 F.2d at 1537, 3 USPQ2d at 1746."22

${ }^{19}$ See Saulsbury, supra note 5, at 448 ("The single embodiment rule's origins have been traced to Engel Industries, Inc v. Lockformer Co., in which the court's principal concern was whether the patentee satisfied the best mode requirement.") (citing Chao); $c f$. Chao, supra note 13, at 18 (discussing earlier cases in which the single embodiment rule was applied in the context of predictable arts).

20 Engel Indus., Inc. v. Lockformer Co., 946 F.2d 1528, 1533 (Fed.Cir.1991).

21 For a discussion of patent law's best mode requirement, or what it once was, see Chisum, supra note 2 , at $\S 15$.

22 Chemcast v. Arco Indus. Corp., 913 F.2d 923, 928 (Fed. Cir. 1990). Unfortunately, Engel's citation of Chemcast carries the potential to confuse: the page of Chemcast that it references (913 F.2d at 929) says nothing about the requirements of enablement. However, the previous page of Chemcast does address enablement (in the context of 
Doctrinal Structure of Enablement - DRAFT

Jason Rantanen

$8 / 9 / 16$

Although that page in Spectra-Physics says nothing about enablement requiring disclosure of "merely a mode of making and using what is claimed," 23 an earlier section of the opinion does. That section states:

If an invention pertains to an art where the results are predictable, e.g., mechanical as opposed to chemical arts, a broad claim can be enabled by disclosure of a single embodiment, In re Cook, 439 F.2d 730, 735, 169 USPQ 298, 301 (CCPA 1971); In re Vickers, 141 F.2d 522, 527, 61 USPQ 122, 127 (CCPA 1944), and is not invalid for lack of enablement simply because it reads on another embodiment of the invention which is inadequately disclosed, see Gould $v$. Mossinghoff, 711 F.2d 396, 400, 219 USPQ 393, 396 (D.C.Cir.1983). Thus, it is sufficient here with respect to enablement that the patents disclose at least one attachment means which would enable a person of ordinary skill in the art to make and use the claimed inventions. Because the patents disclose the alternatives of moly-manganese brazing and pulse-soldering, their failure to also disclose Coherent's TiCuSil braze cycle is not fatal to enablement under $\S 112 .{ }^{24}$

A few paragraphs later, it reinforces this proposition:

Nonenablement is the failure to disclose any mode, In re Glass, 492 F.2d 1228, 1233, 181 USPQ 31, 35 (CCPA 1974), and does not depend on the applicant advocating a particular embodiment or method for making the invention. ${ }^{25}$

At this point, the trail goes cold. Spectra-Physics stands for the unremarkable proposition that a broad claim can be enabled by disclosure of a single embodiment when the art involved is one where the results are predictable (here, two different forms of attaching a metal component to a ceramic component). The cases it cites, too, support this proposition. ${ }^{26}$

distinguishing the separate best mode requirement), containing the quotation provided above.

${ }^{23}$ Page 1537 involves best mode, whereas an earlier section of the opinion involves enablement. The closest text on page 1537 is "For reasons above explained, Coherent's failure to disclose its 'six stage braze cycle' fully supports the defense of non-compliance with the best mode requirement of the first paragraph of $\S 112$ although the inventions as broadly claimed could be practiced without knowledge of it, which means that the patent specifications are enabling."

24 Spectra-Physics v. Coherent, Inc., 827 F.2d 1524, 1533 (Fed. Cir. 1987).

25 Id. at 1534.

${ }^{26}$ See In re Cook, 439 F.2d 730, 735 (C.C.P.A. 1971) ("We agree that appellants' claims are not too broad "to the point of invalidity" just because they read on even a very large number of inoperative embodiments..."); In re Vickers, 141 F.2d 522, 527 


\section{Automotive Technologies and the "full scope" language}

The Federal Circuit's 2007 decision in Automotive Technologies v. BMW offers perhaps the starkest indication of the one mode/full scope split. In Automotive Technologies, the Federal Circuit acknowledged the appellant's contention of a split in the enablement precedent: "According to ATI, there is a dichotomy in our case law-some of our cases hold that the enablement requirement is satisfied when one mode of practicing the invention is enabled, while others hold that every embodiment of the invention must be enabled in order for the enablement requirement to be met."27 Yet, while acknowledging the appellant's contention, it never actually recognized the existence of a split. Instead, it rejected ATI's argument by relying solely on Liebel-Flarsheim in the language quoted in the Introduction. ${ }^{28}$ Ultimately, the court concluded, "[d]isclosure of only mechanical side impact sensors does not permit one skilled in the art to make and use the invention as broadly as it was claimed, which includes electronic side impact sensors." 29

Liebel-Flarsheim, issued a few months earlier, also considered the patent owner's argument that enablement of one embodiment was sufficient. It, too, rejected it. ${ }^{30}$ In reaching this conclusion, the court considered the patent owner's citation of Spectra-Physics and Engel, discussed above, but reasoned that "the facts of this case are, in fact, more analogous to AK Steel than to

(C.C.P.A. 1944) ("We are cognizant of the fact that in a mechanical case an applicant may generally draw a broad claim on a single construction."); Gould v. Mossinghoff, 711 F.2d 396, 400 (D.C. Cir. 1983) ("Under the settled rule that a broad mechanical claim can be supported by disclosure of a single embodiment of the claimed invention, a claim can be sustained even if it covers other inoperative or inadequately disclosed forms of the invention."). In re Glass, 492 F.2d 1228 (C.C.P.A. 1974) does not address the one mode issue at all, let alone support the proposition that "[n]onenablement is the failure to disclose any mode." Instead, what Glass says is "Failure to set forth any mode-which is the situation here-is equivalent to nonenablement." All Glass stands for, then, is that failure to disclose any mode is nonenablement-it does not say that enablement can be satisfied by disclosing any mode. ${ }^{27}$ Auto. Techs. Int'l, Inc. v. BMW of N. Am., Inc., 501 F.3d 1274, 1281 (Fed. Cir. 2007).

28 See supra page 3.

${ }^{29}$ Auto. Techs., 501 F.3d at 1285.

30 The appellant in Liebel-Flarsheim directly raised the one-mode/full scope issue: "With regard to enablement, Liebel contends that the court erroneously considered whether an injector without a pressure jacket was enabled, rather than limiting its inquiry to whether an injector with a pressure jacket was enabled, as it clearly was. Liebel points out that the asserted claims do not recite or require the absence of a pressure jacket and the court improperly focused on such an embodiment. Because it is undisputed that Liebel provided an enabling disclosure of what it calls its preferred embodiment, viz., an injector with a pressure jacket, Liebel asserts that the court should have held that the disclosure was enabling for the full scope of the claims." Liebel-Flarsheim Co. v. Medrad, Inc., 481 F.3d 1371, 1378 (Fed. Cir. 2007). 
Spectra-Physics." 31 The court further quoted AK Steel for the proposition that "as part of the quid pro quo of the patent bargain, the applicant's specification must enable one of ordinary skill in the art to practice the full scope of the claimed invention." 32 That quotation (from AK Steel) ${ }^{33}$ itself quoted In re Wright: "as part of the quid pro quo of the patent bargain, the applicant's specification must enable one of ordinary skill in the art to practice the full scope of the claimed invention." 34

In re Wright further stated that:

Although not explicitly stated in section 112 , to be enabling, the specification of a patent must teach those skilled in the art how to make and use the full scope of the claimed invention without "undue experimentation." Vaeck, 947 F.2d at 495, 20 USPQ2d at 1444; Wands, 858 F.2d at 736-37, 8 USPQ2d at 1404; In re Fisher, 427 F.2d 833, 839, 166 USPQ 18, 24 (CCPA 1970) (the first paragraph of section 112 requires that the scope of protection sought in a claim bear a reasonable correlation to the scope of enablement provided by the specification). ${ }^{35}$

In re Vaeck, in turn, states: "There must be sufficient disclosure, either through illustrative examples or terminology, to teach those of ordinary skill how to make and how to use the invention as broadly as it is claimed." 36 And " $[\mathrm{t}]$ here is no reasonable correlation between the narrow disclosure in appellants' specification and the broad scope of protection sought in the claims encompassing gene expression in any and all cyanobacteria. See In re Fisher, 427 F.2d 833, 839 (C.C.P.A. 1970)." 37 In re Fisher is discussed below in Part I.C.

Each of these cases is notable because they involve the use of enablement as a constraint on maximum permissible claim scope, a feature wellrecognized in both the literature and case law itself. ${ }^{38}$ Both Automotive

${ }^{31}$ Id. at 1380. The court distinguished Spectra-Physics as a case where the "invention as broadly as it was claimed" was enabled: "in that case, disclosure of one attachment means permitted one skilled in the art to make and use the invention as broadly as it was claimed, which included other attachment means known to one of ordinary skill in the art. In contrast, in this case, disclosure of an injector system with a pressure jacket does not permit one skilled in the art to make and use the invention as broadly as it was claimed, including without a pressure jacket."

32 Id. at 1380.

${ }^{33}$ AK Steel v. Sollac, 344 F.3d 1234, 1244 (Fed. Cir. 2003).

${ }^{34}$ In re Wright, 999 F.2d 1557, 1561 (Fed. Cir. 1993).

35 Id.

36 In re Vaeck, 947 F.2d 488, 495 (Fed. Cir. 1991).

37 Id. at 496.

38 See, e.g., Chao, supra note 13; Chiang supra note 13; Rantanen, supra note 3

[Disclosure function]; MagSil Corp. v. Hitachi Glob. Storage Techs., Inc., 687 F.3d 1377, 
Doctrinal Structure of Enablement - DRAFT

Jason Rantanen

$8 / 9 / 16$

Technologies and Liebel-Flarsheim involved claims that encompassed, at the patent owner's own insistence, two distinct embodiments of the invention. ${ }^{39}$ Failure to disclose one of those embodiments proved fatal to the claim encompassing both. AK Steel involved claims that read on two types of coating, whereas the specification disclosed only how to make and use one. ${ }^{40}$ And both In re Wright and In re Vaeck involved claims of great scope relative to the disclosure-particularly so in the case of Wright, where the court characterized Wright as attempting to claim "any and all live, nonpathogenic vaccines, and processes for making such vaccines, which elicit immunoprotective activity in any animal toward any RNA virus." 41 Needless to say, the disclosure was not that broad.

In contrast, as Tun-Jen Chiang, Kevin Collins, and others have pointed out, if only a single mode of practicing the invention is all that is necessary to satisfy enablement, enablement cannot function as a scope-limiting mechanism. ${ }^{42}$ If this is so, then it suggests that the real split is over whether or not enablement can serve to constrain claim scope at all.

\section{B. Working forwards from Tilghman and The Incandescent Lamp Case}

Perhaps the most obvious conclusion to be drawn from the discussion of the Federal Circuit decisions above is that the one mode or embodiment line of cases is, quite simply, wrong. ${ }^{43}$ Even within the Federal Circuit's own case law, the root citation-Spectra-Physics - does not actually say that disclosure of one embodiment is necessarily sufficient for enablement; instead, it merely reiterates a consistent line of cases stating that one embodiment can be sufficient in the predictable arts. The Court of Customs and Patent Appeals (CCPA) cases discussed below further support that conclusion: the CCPA used enablement as a mechanism for limiting claim scope, insisting that the claims be "commensurate" with the disclosure. ${ }^{44}$ Under that approach, sometimes a single disclosed embodiment could be sufficient-but not necessarily. Moreover, the Federal Circuit itself has repeatedly discussed the scopeconstraining purpose of the enablement doctrine. ${ }^{45}$

1380-81 (Fed. Cir. 2012) ("Enablement serves the dual function in the patent system of ensuring adequate disclosure of the claimed invention and of preventing claims broader than the disclosed invention."); LizardTech, Inc. v. Earth Resource Mapping, Inc., 433 F.3d 1373 (Fed. Cir. 2006) (discussing scope-constraining purpose of enablement and written description requirements).

${ }^{39}$ Auto. Techs. Int'l, Inc. v. BMW of N. Am., Inc., 501 F.3d 1274 (Fed. Cir. 2007). LiebelFlarsheim Co. v. Medrad, Inc., 481 F.3d 1371 (Fed. Cir. 2007).

${ }^{40}$ AK Steel, 344 F.3d at 1244.

${ }^{41}$ In re Wright, 999 F.2d 1557, 1562 (Fed. Cir. 1993) (emphasis in original).

42 Tun-Jen Chiang, Fixing Patent Boundaries, 108 MICH. L. REV. 523, 537-38 (2010).

Collins, supra note 16.

${ }^{43}$ Cf. Saulsbury, supra note 11.

44 See infra at 11.

45 See, e.g., LizardTech, Inc., 433 F.3d at 1380; see also Rantanen, supra note 3, at 378. 
Doctrinal Structure of Enablement - DRAFT

Jason Rantanen

$8 / 9 / 16$

And yet, the roots of a "single mode" being necessarily sufficient run far deeper than the CCPA, into $19^{\text {th }}$ Century Supreme Court decisions ${ }^{46}$-as does the apparent doctrinal split described above. While those opinions do not formally make an appearance in support of the Federal Circuit's "one mode" pronouncements, their presence is nonetheless felt. In any event, it is Supreme Court precedent and, not having been overruled by the Court or overridden by Congress, remains worthy of (at a minimum) serious consideration.

The story of the one mode approach to enablement really begins not with Engel, but with the Supreme Court's attempt to deal with challenge of process claims.

During the second half of the $19^{\text {th }}$ century, the Court ruled on a series of cases that involved patent claims over processes and principles. The most famous is arguably $O^{\prime}$ Reilly $v$. Morse, in which Justice Taney, writing for the Court, held Morse's claim 8 to be far broader than the disclosure supported: ${ }^{47}$

"[T]his claim can derive no aid from the specification filed. It is outside of it, and the patentee claims beyond it. And if it stands, it must stand simply on the ground that the broad terms abovementioned were a sufficient description, and entitled him to a patent in terms equally broad. In our judgment the act of Congress cannot be so construed." 48

O'Reilly v. Morse is sometimes viewed as a disclosure case and sometimes as a patentable subject matter case. ${ }^{49}$ Justice Grier, dissenting from the Court's invalidation of claim 8, framed his analysis in terms that we might view more as involving patentable subject matter. ${ }^{50}$ O'Reilly v. Morse defies easy classification, although Justice Taney's choice of language-referring to the relationship between the specification and the claim-fits more easily into the framework of disclosure.

\footnotetext{
46 See Chiang, supra note 5, at 1115, n.122.

47 0’Reilly v. Morse, 56 U.S. 62, 119-20 (1853).

48 Id.

49 See, e.g.. Mayo v. Prometheus, 132 S. Ct. 1289 (2012) (discussing Morse as a patentable subject matter case); Tilghman v. Proctor, 102 U.S. 707 (1880) (framing Morse as a principle/process decision); David J. Kappos, John R. Thomas \& Randall J. Bluestone, A Technological Contribution Requirement for Patentable Subject Matter: Supreme Court Precedent and Policy, 6 Nw. J. Tech. \& Intell. Prop. 152, 156 (describing Morse as "an early landmark decision regarding patentable subject matter"); Jeffrey A. Lefstin, The Formal Structure of Patent Law and the Limits of Enablement, 23 BERKELY TECH. L.J. 1141, 1152 n.35 (2008) (discussing Morse as a disclosure case). 50 O’Reilly v. Morse, 56 U.S. 62, 132 (1853) (Grier, J., dissenting).
} 
By the 1880s, however, the Court had moved to a framing of $O^{\prime}$ Reilly $v$. Morse as involving the distinction between patentable processes and unpatentable principles. ${ }^{51}$ In a series of decision in the 1880 s and 1890 s, the Court laid out two central holdings relating to process claims. First, patent claims on processes are permissible, as long as the claim is not to the principle itself; and second, that patent claims on processes are adequately supported by disclosure of a single mode or embodiment of that process. ${ }^{52}$

The Court in these cases was only loosely concerned with the breadth of the patent claims. Indeed, the claim in the Court's 1880 decision in Tilghman $v$. Proctor was arguably quite broad compared to the specific embodiment disclosed in the patent. ${ }^{53}$ Preexisting methods for producing fatty acids involved the use of lime. Dr. Tilghman discovered a method for producing fatty acids without the use of lime by heating the fat plus an equal part of water to a high temperature (around 500-600 degrees Fahrenheit). ${ }^{54}$ The accused infringers also heated the mixture, but varied the approach: introducing steam rather than heating the water in a sealed vessel, heating the water to 310 degrees Fahrenheit, and adding a small quantity of lime (substantially less than the existing methods). ${ }^{55}$ The Court concluded both that Dr. Tilghman was entitled to a claim for his process and that the accused company infringed. ${ }^{56}$

In reaching this conclusion, the Court stated that:

[i]f the mode of applying the process is not obvious, then a description of a particular mode by which it may be applied is sufficient. There is, then, a description of the process and of one practical mode in which it may be applied. Perhaps the process is susceptible of being applied in many modes and by the use of many forms of apparatus. The inventor is not bound to describe them all in order to secure to himself the exclusive right to the process, if he is really its inventor or discoverer. But he must describe some particular mode, or some apparatus, by which the process can be applied with at least some beneficial result, in order to show that it is capable of being exhibited and performed in actual experience. ${ }^{57}$

\footnotetext{
51 See Tilghman v. Proctor, 102 U.S. 707 (1881); Dolbear v. Am. Bell Tel. Co., 126 U.S. 1 (1888).

52 See id.

53 Tilghman v. Proctor, 102 U.S. 707 (1881).

54 Id. at $720-21$.

55 Id. at 732-33.

56 Id. at 734 .

57 Id. at 728-29 (emphasis added).
} 
Seven years later, in Dolbear v. Am. Bell Tel. Co., ${ }^{58}$ the Court reiterated the single mode proposition:
"The law does not require that a discoverer or inventor, in order to get a patent for a process, must have succeeded in bringing his art to the highest degree of perfection; it is enough if he describes his method with sufficient clearness and precision to enable those skilled in the matter to understand what the process is, and if he points out some practicable way of putting it into operation."59

The 1895 edition of WALKER ON PATENTS, a contemporaneous treatise, stated that "Neither is it necessary in a patent for a process to set forth all the modes in which that process may be performed, nor all the kinds of apparatus which may be used in performing it, in order to cover that process with the patent. It is enough to describe one particular mode and one particular apparatus by means of which the process may be performed with at least some beneficial result." 60

At the same time, however, the Court was hardly oblivious to concerns about the relationship between the disclosure and the claim. Even as it upheld Alexander Graham Bell's broad claim in Dolbear v. American Telephone, ${ }^{61}$ it rejected the claims of Sawyer and Man as too broad relative to the disclosure in the Incandescent Lamp Case. ${ }^{62}$ In that case, well-known to students of patent law, the Court concluded that the broad claims far exceeded the disclosure, thus rendering the claims invalid. ${ }^{63}$

58 Dolbear v. Am. Bell Tel. Co., 126 U.S. 1 (1888). In correspondence about this Essay, Jeffrey Lefstin emphasized that these statements in Tilghman and Dolbear follow the Court's quotation from Morse, "where the Court emphasized the difference between an invention where the disclosure enabled universal application of the discovery (Neilson) and where it did not (Morse)." 5/27/2016 1:58 P.M. email. I read the discussion differently, as distinguishing between a claim where the disclosure was sufficient (Neilson) and one where no disclosure could ever be sufficient because the claim was to a principle (Morse). Cf. Tilghman, 102 U.S. at 726-27 ("It was not a claim of any particular machinery, nor a claim of ay particular process for utilizing the power, but a claim of the power itself, --a claim put forward on the ground that the patentee was the first to discover that it could be the thus employed. This claim the court held could not be sustained."). For reasons that will become apparent, both views are valid once the "split" is reconciled in Part III.

59 Dolbear, 126 U.S. at 536; see also Morley Sewing Mach. Co. v. Lancaster, 129 U.S. 263 (1889) (similar point, but presented in a much wordier fashion). 60 WALKER ON PATENTS (1895), at 154-55 (§ 175) (emphasis added).

61 Dolbear, 26 U.S. at 534 ("What Bell claims is the art of creating changes of intensity in a continuous current of electricity, exactly corresponding to the changes of density in the air caused by the vibrations which accompany vocal or other sounds, and of using that electrical condition, thus created, for sending and receiving articulate speech telegraphically.").

62 Consolidated Electric Light Co. v. McKeesport Light Co., 159 U.S. 465 (1895).

63 Id. 
The "hair refining" case of Bene v. Jeantet provides another example:

Tested by [the requirement of $\S 4888$ ], the patent in suit cannot receive the broad construction for which complainants contend. Except as applicable to the second claim, the specification is not full and clear enough to give one skilled in chemistry such an idea of the particular kinds and character of the chemicals, or combination of chemicals, with the relative proportions of each, as would enable him to use the invention without having to resort to experiments of his own to discover those ingredients. The broad construction claimed for this patent as a pioneer and foundation invention in the art of refining hair cannot extend the rights of the patentee beyond the compositions of matter and processes which, as stated in the patent, embody his real invention.... ${ }^{64}$

Taken at face value, these cases exhibit the same one mode/full scope split as the recent Federal Circuit decisions discussed in part I.A. And while one might be tempted to draw a distinction based on the nature of the "one mode" cases as "process" claims, note that Bene v. Jeantet, too, involved claims to a process. ${ }^{65}$ The existence of this "split" in the Supreme Court decisions of the $19^{\text {th }}$ Century implies a conclusion, if not the reasoning: that what commentators perceive as "irreconcilable" cases ${ }^{66}$ are perhaps not.

\section{The CCPA and "Commensurate"}

Were it that the history of enablement were so simple, however. There remains one important piece: the Court of Customs and Patent Appeals, which, as Jeffrey Lefstin has argued, "bequeathed to us the constitution of modern patent law."67 That court was responsible for reviewing decisions of the Patent Office during the decades before the creation of the Federal Circuit in 1982.

Professor Lefstin observed that, prior to the actions of the Court of Customs and Patent Appeals in the 1960s and '70s, much of patent doctrine took the form of a "heterogeneous collection." 68 From this, the CCPA distilled

64 Bene v. Jeantet, 129 U.S. 683, 686 (1889); see also Lawther v. Hamilton, 124 U.S. 1 (1888) (limiting scope of claims based on what was disclosed.); Cochrane v. Badisch Anilin \& Soda Fabrick, 111 U.S. 293, 313 (same) (1884).

65 Id. at 685 (referring to the "patented process").

${ }^{66}$ Chiang, supra note 13 , at 1117.

${ }^{67}$ Jeffrey A. Lefstin, The Constitution of Patent Law: The Court of Customs and Patent Appeals and the Shape of the Federal Circuit's Jurisprudence, 43 LOY. L.A. L. REV. 843, 892 (2010). Lefstin provides a rich history of the CCPA and its impact on modern patent law.

68 Id. at 865. [Constitution]; Lefstin writes: "In the decades prior to and immediately following the 1952 Patent Act, the Patent Office and the courts frequently cited 'undue 
and crystallized the patent law into a series of conceptually formal doctrines. Enablement, in particular, was shaped by the CCPA's decisions during this era. ${ }^{69}$

In a series of decisions during the 1970s, the CCPA moved to limit doctrinal constraints on claim scope to the enablement and written description requirements of 35 U.S.C. $§ 112$, first paragraph. ${ }^{70}$ In re Swinehart illustrates the court's move. This case unequivocally states that functional language-a common ground for holding claims to be too broad during the previous decades ${ }^{71}$ - does not raise a scope-based indefiniteness issue under $\S$ 112 , second paragraph. Instead, the only issue under that paragraph is whether "the language used is not precise and definite enough to provide a clear-cut indication of the scope of subject matter embraced by the claim."72 And the only issue under $\S 112$, first paragraph is "that the language is so broad that it causes the claim to have a potential scope of protection beyond that which is justified by the specification disclosure."73 Applying this framework, the court concluded that the patent office had not raised a scopebased concern based on the relationship between the claim and the disclosure, and that despite the use of functional language, the language of the claims met

breadth' to reject or invalidate claims for a wide variety of faults. Subsumed under the category of 'undue breadth' were rejections based on all of the following: inclusion of nonstatutory subject matter (such as mental steps); lack of utility; divergence between the applicant's subjective view of the invention and the subject matter encompassed by the claim; failure of the claim to precisely delineate the subject matter of the patent; presence of inoperable species within the ranges defined by the claim; insufficient working examples or other guidance compared to the scope of the claim; and even what we would today categorize as obviousness."

${ }^{69}$ See Lefstin, supra note 67, at 865-67. See also Mark D. Janis, Who's Afraid of Functional Claims? Reforming the Patent Law's $\S 112, \mathbb{1} 6$ Jurisprudence, 15 SANTA ClARA COMP. \& High TECH. L.J. 231 (1999).

${ }^{70}$ See In re Borkowski, 422 F.2d 904 (C.C.P.A. 1970); In re Swinehart, 439 F.2d 210, 213 (C.C.P.A. 1971); Lefstin, supra note 65, at 866.

${ }^{71}$ See Holland Furniture Co. v. Perkins Glue Co., 277 U.S. 245 (1928) ("That the patentee may not by claiming a patent on the result or function of a machine extend his patent to devices or mechanisms not described in the patent is well understood."); Gen. Elec. Co. v. Wabash Appliance Corp., 304 U.S. 364, 371 (1938) ("The claim uses indeterminate adjectives which describe the function of the grains to the exclusion of any structural definition, and thus falls within the condemnation of the doctrine that a patentee may not broaden his product claims by describing the product in terms of function."); Halliburton Oil Well Cementing Co. v. Walker, 329 U.S. 1 (1946) ("Under these circumstances the broadness, ambiguity, and overhanging threat of the functional claim of Walker become apparent").

72 In re Swinehart, 439 F.2d 210, 213 (C.C.P.A. 1971).

${ }^{73} \mathrm{Id}$. The court continued on to state that " $[\mathrm{t}]$ his ground of rejection is now recognized as stemming from the requirements of the first paragraph of 35 U.S.C. $\S$ 112." 
the requirement to be "precise and definite enough to provide a clear-cut indication of the scope of subject matter embraced by the claim."74

The court's second decision in In re Fisher offers another example. ${ }^{75}$ The claim in that case was as an open-ended results-oriented claim ("potency of 'at least 1'") in which the CCPA reversed the patent office's rejection of the claims on indefiniteness grounds, instead concluding that the claims were invalid on enablement grounds:

[35 U.S.C. $§ 112$, first paragraph] requires that the scope of the claims must bear a reasonable correlation to the scope of enablement provided by the specification to persons of ordinary skill in the art. In cases involving predictable factors, such as mechanical or electrical elements, a single embodiment provides broad enablement in the sense that, once imagined, other embodiments can be made without difficulty and their performance characteristics predicted by resort to known scientific laws. In cases involving unpredictable factors, such as most chemical reactions and physiological activity, the scope of enablement obviously varies inversely with the degree of unpredictability of the factors involved. In the present case we must conclude, on the record before us, that appellant has not enabled the preparation of ACTHs having potencies much greater than 2.3, and the claim recitations of potency of 'at least 1 ' render the claims insufficiently supported under the first paragraph of 35 U.S.C. $§ 112 .^{76}$

The concept expressed in In re Fisher II that "the scope of the claims must bear a reasonable correlation to the scope of enablement provided by the specification to persons of ordinary skill in the art" embodies the CCPA's legal mechanism for constraining claim scope: the requirement that scope of enablement be "commensurate" with the scope of the claims. ${ }^{77}$

\footnotetext{
${ }^{74} I d$.

75 In re Fisher, 427 F.2d 833 (C.C.P.A. 1970) (Fisher II). Fisher II rejected the approach of the court in the same case a few years earlier. See In re Fisher, 307 F.2d 948 (C.C.P.A. 1962).

76 Fisher II, 427 F.2d at 1108.

77 See In re Moore, 439 F.2d 1232, 1236 (C.C.P.A. 1971) ("The relevant inquiry may be summed up as being whether the scope of enablement provided to one of ordinary skill in the art by the disclosure is such as to be commensurate with the scope of protection sought by the claims."). The origins of the "commensurate" language for claim scope date back to at least In re Williams, 168 F.2d 525, 526 (C.C.P.A. 1948) ("His claims should be made commensurate in scope with his invention."), and probably earlier. See In re Ferris, 90 F.2d 363 (C.C.P.A. 1937) ("In equity the law is well settled 'that an inventor is entitled to a range of equivalents commensurate with the scope of his invention.' WALKER ON PATENTS (6th Ed.)"). But the terminology
} 
By the mid-1970s, the "commensurability" requirement in enablement was well established as the CCPA's primary mechanism for limiting claim scope. ${ }^{78}$ As a mechanism, though, it imposed little in the way of legal constraints on the CCPA itself. Instead, it operated so as to permit the CCPA judges to exercise their views on the worthiness of any inventor's contribution to the art. Such a flexible mechanism made sense in the context of the historical times, where the court's structure allowed it to function as a collegial and deliberative unit ${ }^{79}$ that exercised its own judgment independent of any concepts of deference to a lower tribunal. ${ }^{80}$

Judge Markey's opinion in In re Hogan illustrates both the dominance of the "commensurate" approach to enablement and the flexibility it allowed the court: "Rejections under $\S 112$, first paragraph, on the ground that the scope of enablement is not commensurate with the scope of the claims, orbit about the more fundamental question: to what scope of protection is this applicant's particular contribution to the art entitled?" 81 Here, that question turned-in Markey's view at least-on whether or not the invention was of "pioneering" status: "As pioneers, if such they be, they would deserve broad claims to the broad concept. What were once referred to as "basic inventions" have led to "basic patents, which amounted to real incentives, not only to invention and its

comes into heavy use in the CCPA's opinions in the mid-1960s and 1970s, when the court deploys to the primary mechanism for limiting claim scope.

${ }^{78}$ Here, I use "commensurability" as shorthand for the requirement that the disclosure be commensurate with the scope of the claims. To my knowledge, the CCPA did not use this shorthand. The first use of the term in the literature appears to be Karen S. Canady, The Wright Enabling Disclosure for Biotechnology Patents, 69 WASH. L. REV. 455, 466 (1994). ${ }^{79}$ See Lefstin, supra note 67, at 856. Lefstin describes this "uniquely situated court": "[t]he court's structure and vantage point gave rise to a body of law to be wielded by experienced judges with the time and inclination to delve deeply into questions of patentability. Those judges would be free to decide appeals largely according to their own views, unhindered by the constraint of deference to a lower tribunal. The CCPA's intimacy meant that positions adopoed by the court usually commanded a majority of the court's judges, while the flexibility provided by always sitting en banc permitted the court to revise its doctrine and policy choices relatively freely." 80 See Lefstin, supra note 67, at 852 (quoting Judge Giles S. Rich for the comment that "In the CCPA, we were not reviewing trials, and Rule 52(a) was not applicable. Or if it was, we ignored it. Reviewing the PTO boards, our attitude was we reversed them if they were wrong.").

${ }^{81}$ In re Hogan, 559 F.2d 595, 606-607 (C.C.P.A. 1977). 
disclosure, but to its prompt, early disclosure." 82 In Judge Markey's view, the pioneering status of an invention mattered; not so to others. ${ }^{83}$

In light of this history, recent enablement cases might be seen as constituting not a new development but the reincarnation of a long-standing schism in patent law. One way of resolving this split, then, would be to do as the CCPA judges did in the 1970s: using the rubric of "commensurability," reject the use of rigid, formal rules and instead decide enablement-scope issues on a case-by-case basis depending on the sense of the judges. But while this approach may have worked for the five-judge CCPA, which decided every case en banc, it fits less well with a twelve-plus-judge Federal Circuit that decides most cases as a three judge panel. A fuzzy, rule-light approach also does not fit well with the Federal Circuit's own jurisprudential approach, which tends to favor clear rules over soft standards and is constrained by the evolving role of deference to the tribunals it reviews. ${ }^{84}$ It also fails to resolve the apparent tension existing in the older Supreme Court precedent.

This, then is the question: is there a way to reconcile the one mode/full scope split other than through the fuzzy, judge-dependent approach of the CCPA in the 1970s? The answer, as discussed in the next section, is yes.

\section{IMPLICIT DOCTRINE AND THE ENABLEMENT REQUIREMENT}

\section{A. On the Nature of Legal Doctrine}

${ }^{82}$ Id. at 606. Any discussion of Judge Markey's opinion in In re Hogan would not be complete without noting that he viewed the question before the court as one of patentability issues arising during an infringement proceeding, he thought, could be dealt with through the "reverse doctrine of equivalents." Id. at 607; $c f$. Lefstin, supra note 66 , at $855-56$.

${ }^{83}$ Not every one shares (or shared) Judge Markey's view that "pioneering" inventions possess a special entitlement to broad claim scope. See Plant Genetic Systems, N.V.v. DeKalb Genetics Corporation, 315 F.3d 1335, 1341 (Fed. Cir. 2003), where Judge Michel wrote:

Regarding PGS' extensive citation of statements from Hogan such as that pioneering inventions "deserve broad claims to the broad concept," id. at 606, we conclude that they are taken out of context and thus unconvincing. As the concurrence in Hogan pointed out, these statements are "extended dicta." Id. at 610. We do not need to address all of the insightful comments made by the concurring judge; it is sufficient for the present case that we hold the district court did not err in not applying Hogan's dicta to its enablement analysis.

84 See, e.g., Lefstin, supra note 67, at 871-78 (describing the challenges faced by the Federal Circuit after it adopted the CCPA's precedent as its own). 
To answer the question of how this split in enablement doctrine can be reconciled, it is first necessary to establish common ground on the nature of legal doctrine: in other words, when we talk about legal doctrine, what exactly is it that we're talking about? For, it turns out, even setting aside the debate between legal realism and legal doctrine, there are many different perspectives on the nature of legal doctrine. ${ }^{85}$

This Essay views legal doctrine as meaning the collection of legal "stuff" that together forms a choate (and sometimes inchoate) legal whole that provides the analytical framework in which legal decisionmakers, judicial and otherwise, make their decisions. Black's Law Dictionary defines the term as “A rule, principle, theory, or tenet of the law, as the doctrine of merger, the doctrine of relation, etc." 86 In the narrow sense, "doctrine" can be thought of as a single rule, a single principle, a single theory. But doctrine can also be thought of in the collective sense, as all the different bits of law that together make up a given framework for analyzing a legal question. ${ }^{87}$ "Enablement doctrine" is employed in that broad sense: it refers to all the various legal "stuff" that make up the overarching principle of enablement.

85 As an example of different perspectives on legal doctrine, see U. PENN. L. REV. Volume 163, which contains articles from the Pennsylvania Law Review's symposium "The New Doctrinalism." See also Emerson H. Tiller \& Frank B. Cross, What is Legal Doctrine?, 100 Nw. U. L. REv. 517 (2006). This Essay takes, as legal scholars often do, doctrine at its face value but recognizes the implications of realism-based effects on the outcomes reached by individual judges. In other word, it treats legal doctrine as forming the analytical backbone of proper judicial analysis and not merely as posthoc window dressing used to cloak a decision in the trappings of legitimacy.

Perhaps the existence of this doctrinal split can be resolved simply by reference to legal realism and panel dependence. Different judges have different ideologies and different panels can produce different lines of contradictory precedent. See Lighting Ballast Control LLC v. Philips Electronics North America, 744 F.3d 1272, 1313 (Judge O'Malley in dissent) (summarizing evidence of panel dependence in claim construction); See John Henry Schlegal, Legal Realism, in THE OXFord COMPANION TO AMERICAN LAW, Kermit L. Hall, ed. (2002 But grasping at legal realism as if it were magic talisman that solves everything is taking the easy way out, and does an injustice to judges and lawyers who really do rigorously analyze legal problems. This is not to say that legal realist claims are completely hollow, but rather that oftentimes legal doctrine really does provide the analytical framework within which decisionmakers make their decisions. C.f. Tiller \& Cross.

This Essay takes up that challenging task: to examine whether the split in enablement law can be resolved through doctrinal analysis and reasoning alone. Legal realism has value, but so too does a better understanding of legal doctrine. 86 Doctrine, BLACK'S LAW DictionaRY (10th ed. 2014).

87 See Brian Leiter, Legal Realism and Legal Doctrine, 163 U. PA. L. REV. 1975 (2015). Melissa Murray, Family Law's Doctrines, 163 U. PA. L. REV.1985 (2015). 
But then, what is that "stuff"? Unpacking the concept, I see the doctrine of enablement as existing in four basic layers: ${ }^{88}$ (1) statutory language, (2) formal statements of the law in cases, (3) case analogies, and a fourth layer that I will describe shortly.

The first layer consists of statutory language. In the case of the enablement doctrine, what the statute says isn't all that controversial. ${ }^{89}$ The 35 U.S.C. $§ 112(a)$ language that has remained surprisingly similar since 1790:

The specification shall contain a written description of the invention, and of the manner and process of making and using it, in such full, clear, concise, and exact terms as to enable any person skilled in the art to which it pertains, or with which it is most nearly connected, to make and use the same, and shall set forth the best mode contemplated by the inventor or joint inventor of carrying out the invention. ${ }^{90}$

The second layer of doctrine consists of formal statements of the law in cases. These may be interpretations of the statute or extra-statutory statements of what the law is; they may be rules, they may be standards. Finding them in an opinion is usually easy, since oftentimes the court comes right out and says something like "the law is X." An example in enablement law is the principle that some experimentation is permissible, as long as it is not "undue": "Although not explicitly stated in $\S 112$, to be enabling, the specification of a patent must teach those skilled in the art how to make and use the full scope of the claimed invention without "undue experimentation." 1

The first and second layers comprise "express" or "formal" doctrine: relatively clear, positive statements of the law by courts; law often referred to as "blackletter." This type of doctrine is explicit. Beginning law students often struggle to spot formal legal doctrine in judicial opinions, but by the time they graduate it should practically leap off the page.

The third layer of doctrine consists of case analogies. Case analogies tend to be fact-based, although "fact" can be understood broadly to encompass characteristics such as an earlier decision's procedural posture. An example of a case analogy in the enablement space would be to point to a patent in a prior decision and say "the court found that claim to be enabled, so you should find the claim at issue in this case to be enabled because it's very similar to the

${ }^{88}$ Arguably, U.S. ConST. art. I, §8, cl. 8 of the Federal Constitution provides an antecedent layer in patent law. But it rarely functions as a standalone doctrinal layer. Instead, it tends to affect the other layers in different, often indirect, ways. 89 Unlike with the written description doctrine.

9035 U.S.C. § 112(a) (2016).

91 In re Wright, 999 F.2d 1557, 1561 (Fed. Cir. 1993); see also Magsil Corp. v. Hitachi Glob. Storage Techs., Inc., 687 F.3d 1377, 1380 (Fed. Cir. 2012); Genentech, Inc. v. Novo Nordisk, A/S, 108 F.3d 1361, 1365 (Fed. Cir. 1997). 
claim in the previous case."92 This layer of doctrine is important, but because case analogies are highly fact-specific it's hard to identify doctrinal contours with them.

Not everyone may agree with this description of legal doctrine. Some may, for example, view doctrine as consisting entirely of statutes and case outcomes. ${ }^{93}$ At this end of the spectrum, all statements about the law made in cases are simply dicta. ${ }^{94}$ The contents of legal doctrine, and precedent, are thus limited to only the directional outcome of decisions on a given set of facts, and future decisions are determined through reasoning by example. ${ }^{95}$

But this view of legal doctrine does not reflect the way much of patent law, at least, operates. Courts routinely draw upon statements made in prior cases without reference to their facts or outcome, giving legal weight to what the court said in the prior opinion rather than its decisional outcome. In the patent law space, for example, consider the framework for analyzing nonobviousness set out by the Supreme Court in Graham v. John Deere. ${ }^{96}$ Courts have recited the language of Graham hundreds (if not thousands) of times solely for the framework itself. ${ }^{97}$ That the Court concluded that Graham's patented invention was obvious is relevant to some disputes, but it is the Graham framework that has had real lasting power. Patent law is replete with other examples of judicial statements about the law that themselves constitute the primary framework of legal doctrine. ${ }^{98}$

${ }^{92}$ Cf. Liebel-Farsheim Co. v. Medrad, Inc., 481 F.3d 1371 (Fed. Cir. 2007) (discussing other opinions and reasoning by analogy).

93 Thanks to Andres Sawicki for suggesting this position.

${ }^{94}$ Cf. Edward H. Levi, An Introduction to Legal Reasoning, 15 U. CHI. L. REV. 501, 502-3 (1948) (the existence or absence of facts which prior judges thought important.). ${ }^{95} \mathrm{Cf}$. Id. at 502 ("The determination of similarity or difference is the function of each judge. Where case law is considered, and there is no statute, he is not bound by the statement of the rule of law made by the prior judge even in the controlling case. The statement is mere dictum, and this means that the judge in the present case may find irrelevant the existence or absence of facts which prior judges thought important."). 96 Graham v. John Deere Co., 383 U.S. 1, 17 (1966) ("Under § 103, the scope and content of the prior art are to be determined; differences between the prior art and the claims at issue are to be ascertained; and the level of ordinary skill in the pertinent art resolved.").

97 Based on my systematic review of all Federal Circuit decisions on nonobviousness during the ten-year period preceding, and five year period following, KSR v. Teleflex. The court's use of Graham v. John Deere in In re Haung, 100 F.3d 135, 138 (Fed. Cir. 1996) (reciting the Graham framework), is representative.

98 In addition to the "without undue experimentation" statement above, other examples include (but are hardly limited to): statements framing the nonobviousness inquiry in KSR Int'l Co. v. Teleflex Inc., 550 U.S. 398 (2007); the framing of the written description inquiry as involving "possession" in Ariad Pharms., Inc. v. Eli Lilly \& Co., 598 F.3d 1336, 1352 (Fed. Cir. 2010), see also Lisa Larrimore Ouellette, Pierson, Peer Review, and Patent Law, 69 VAND. L. REV. (forthcoming 2016); the framework for analyzing on-sale bar issues set out in Pfaff v. Wells Elecs., Inc., 525 U.S. 55, 66-67 
Others may take the opposite position and view case analogies as not constituting doctrine at all, at least until the comparison is written into a judicial opinion. ${ }^{99}$ In other words, the outcome of a case only matters once the court analyzes that outcome in the context of another decision and agrees with (or disagrees with) a party's reasoning as to why the outcome of that case matters, then sets out a general rule of law that flows from the original case. Until that happens, case outcomes are simply potential doctrine, waiting to be used. At the extreme, this position, too, seems to not really reflect what occurs in judicial decisionmaking: outcomes of previous cases can matter-that is why courts actually consider them in their analyses. And while a single case outcome may not rise to the level of doctrine by itself, resolutions of particular legal disputes are rarely singular in nature. ${ }^{100}$ Ultimately, whether unanalyzed cases are doctrine or merely doctrine in potentia may be a difference without substance. In any event, this Essay is not a treatise on doctrine itself; that is another project. It simply seeks to set out a framework for analyzing an apparent tension within the enablement doctrine.

Within this unpacking of doctrine, the one mode/full scope split exists at the second layer: formal statements of the law in judicial opinions. The court, in interpreting the statutory requirement and its own precedent interpreting that requirement, makes certain legal statements that themselves have precedential value: statements that control and limit future applications of the doctrine. Each of the opinions discussed in Part I involves such a formal statement. Unfortunately, those formal articulations of the law seem to contradict one another; to represent directly opposed conceptions of the enablement requirement. Case analogies can help, but as Liebel-Flarsheim's attempt to draw upon them in its analysis shows, they are about as likely to satisfy one's hunger for guiding analysis as cotton candy. This is because case analogies, by themselves, provide only points of reference rather the broader guiding principles.

But there is a fourth layer of doctrine, one that does not manifest in the express language of the statute or judicial opinion: implicit doctrine. By implicit doctrine I mean the components of legal analysis of a given issue that are present but not formally articulated in either the statute or a court's formal statements of the law. ${ }^{101}$ The concept of "implicit doctrine" goes by many

(1998); the "reasonable certainty" standard of indefiniteness provided in Nautilus, Inc. v. Biosig Instruments, Inc., 134 S. Ct. 2120 (2014)]], and much, much more. 99 Thanks to Jonas Anderson for suggesting this position.

100 For an example of a case relying both on reasoning by application of what the court said in the prior case and reasoning by example, see Bascom Glob. Internet Servs., Inc. v. AT\&T Mobility LLC, 2016 WL 3514158 (Fed. Cir. June 27, 2016). 101 As far as I am aware, there is no previous use of "implicit doctrine" as a term for this concept. The term does appear in a handful of references, however, with the most commonly cited being the Alabama Supreme Court's statement "[i]n Alabama, separation of powers is not merely an implicit "doctrine" but rather an express command; a command stated with a forcefulness rivaled by few, if any, similar provisions in constitutions of other sovereigns." Ex parte James, 836 So.2d 813, 815 
names, and sometimes none at all. Tun-Jen Chiang, for example, frames a discussion of the "levels of abstraction" problem in patent law in these terms: "By remaining entirely silent about how the choice among conflicting cases is made-i.e., by remaining silent about the real decisionmaking process-courts create confusion and unpredictability for everyone."102 Kevin Collins explains that he "distills the most conceptually coherent and normatively justified rule set that still maintains a reasonable fit with data." 103 What each of these scholars is fundamentally attempting to do is to identify and figure out the unstated components of courts' legal analysis.

Of course, due to its unstated nature, implicit doctrine is more elusive than formal, explicitly stated doctrine. Thus, it is only when it rises to a certain level of identifiability, persistence and commonality that we can describe it as doctrine. And sometimes, when courts articulate the unstated, implicit components of their analysis, implicit doctrine can become the formal, express doctrine described above.

In the case of enablement doctrine, there are at least two components of analytical structure that rise to the level of identifiability, persistence and commonality necessary to constitute implicit doctrine. The first is inherent in how the enablement determination plays out, while the second is an unstated but often carried out and determinative step in resolving questions of enablement.

\section{B. The form of legal disputes over enablement}

The first step in unraveling the puzzle of the one mode/full scope split is to recognize that the enablement requirement does not impose a positive obligation on the applicant or patent owner. In other words, patent law does not require inventors to prove that their claims are enabled to their full hypoethtical scope; rather, the only context in which enablement is at issue is when someone other than the inventor challenges the enablement of a claim. This is true when the inventor applies for the patent at the patent office, as discussed by Sean Seymore, ${ }^{104}$ and it is of course true in litigation, where the patent is imbued with a presumption of validity. ${ }^{105}$

(Ala. 2002). Other commentators invoke the term "implicit doctrine," but do not unpack what they mean by this pair of words. See, e.g., Johanna S. Schiavoni, Who's Afraid of Precedent?: The Debate over the Precedential Value of Unpublished Opinions, 49 UCLA L. REV. 1859, 1868 (2002) ("Because these commentators so heavily influenced the beliefs of the Framers, the argument follows that the Framers subscribed to this declaratory theory of adjudication and its implicit doctrine of precedent.").

102 Chiang, supra note 66, at 1124 [Levels of Abstraction].

103 Collins, supra note 15, at 1094 [Enabling AAT].

104 See generally Seymore, supra note 22 (describing the "presumption of patentability"). As Seymore observes, this presumption of patentability is not merely true of enablement-it is also true for issues of patentability generally. 105 See 35 U.S.C. $§ 282$ (2016). 
In other words, the issue of enablement only manifests when a challenger contends that a claim is not enabled. The patent owner never has the burden to demonstrate that a claim is enabled as a general matter; only to defeat a given challenge. Put another way, a patent owner need not demonstrate that it is entitled to the full scope of the claim in an absolute sense; it need only defeat any challenges that are raised against it.

The consequence of this structure is that the only time enablement becomes an issue is when someone articulates an enablement challenge-and the articulation of the challenge is what matters, as opposed to whatever the hypothetical contours of the patent claim may be in the abstract. The application of the enablement requirement thus takes the following form: Someone issues a challenge: "given the disclosure in the specification, could a person having ordinary skill in the art (a "PHOSITA" in patent lingo) make and use the claimed invention?"106

Or put in conceptual terms, could a PHOSITA, using the disclosure in the specification and a bit of experimentation, hit a given target? Visualize a PHOSITA as an archer aiming at a straw target. Given the disclosure in the specification, could the PHOSITA hit that target? If the PHOSITA would succeed, the challenge is won and the enablement issue is over. If the arrow misses the target, or fails to reach it entirely, then the challenge is lost and the claims are held to lack enablement. ${ }^{107}$

The nature of the enablement determination as a challenge is a critical, inherent component of the enablement doctrine. Every enablement dispute decided by a court begins as a challenge, and it is only in the contours of the challenge as articulated that enablement can be decided.

\section{The determinative nature of target articulation}

If enablement questions always take the form of a challenge to hit a target, the next step in the analysis should suggest itself: there must be a target for the PHOSITA to attempt to reach. It is this step-the articulation of a target-that forms a critical, determinative step in resolving an enablement dispute. And yet, it is an unstated, implicit component of the enablement analysis rather than one that has been expressly spelled out in the Federal Circuit's enablement jurisprudence. ${ }^{108}$

The simplest form of an enablement challenge arises when the challenger articulates a single target and contends that the patent applicant or owner

${ }^{106} \mathrm{Cf}$. Seymore, supra note 22, at 997-1002 (describing the process by which an examiner goes through to make a prima facie rejection of a claim due to nonenablement).

107 In this analogy, experimentation that is not "undue" allows the arrow to reach further. Non-undue experimentation can also operate to allow one arrow to hit the multiple targets discussed in the following section.

108 One can search the enablement chapter (chapter 7) in CHISUM ON PATENTS in vain for a discussion of this necessary step. 
cannot hit that target. In patent terms, the challenger contends that the disclosure of a patent does not allow a PHOSITA to make or use any embodiment of the claims. An example is provided by Old Town Canoe v. Confluence Holdings. ${ }^{109}$ There, the challenger contended that the patent was not enabled "because it failed to set forth the time and temperature parameters for the molding process." 110 Absent these parameters, a person skilled in the art would not be able to "practice the invention disclosed in the '963 patent" without engaging in undue experimentation. Framed in these terms, the Federal Circuit agreed that the evidence could support a claim the patent was not enabled. ${ }^{111}$ On the other hand, in Moba v. Diamond Automation, the challenger contended that "the specification does not enable one of ordinary skill in the art to lift eggs from a moving conveyor belt without undue experimentation." 112 But the jury rejected the challenger's evidentiary support for this argument, a finding affirmed by the Federal Circuit on appeal. ${ }^{113}$ These cases illustrate a single target presented by the challenger.

Importantly, for any single target, only one way of reaching that target must be provided. When the court approaches the question of whether a given target is enabled, the issue in the arrow analogy is whether the arrow hits the target at all. It is not necessary to also hit the target with a bullet, a baseball, a Frisbee, a chicken, etc. The only question is whether there is at least one way to reach that particular target. For any given target identified by the court, enablement of a single mode is sufficient. 114

Takeda $v$. Zydus illustrates this point. ${ }^{115}$ There, the target required a skilled artisan to be able to measure particle diameter. ${ }^{116}$ It was undisputed that a skilled artisan could measure particle size using two techniques, "laser diffraction and/or optical microscopy."117 Given the availability of these two techniques, it did not matter that a third technique, coulter counter, would have required undue experimentation. ${ }^{118}$ The available measurement techniques were enough for the claim to be enabled.

But a challenger need not articulate only a single target. Instead, it often articulates the challenge as if there are multiple targets, each which must be enabled. In this situation, the challenger is not contending that a single target

109 Old Town Canoe Co. v. Confluence Holdings Corp., 448 F.3d 1309, 1319-20 (Fed. Cir. 2006).

110 Id. at 1319.

111 Id. at 1320.

112 Moba B.V. v. Diamond Automation, Inc., 325 F.3d 1306, 1321 (Fed. Cir. 2003).

113 Id.

${ }^{114}$ Cf. Saulsbury, supra note 5, at 461 (observing that "[n] one of [the Federal Circuit's

full scope decisions] even considered whether a claim was invalid for failure to disclose an alternative method of making or using the claimed invention."). 115 Takeda Pharm. Co. v. Zydus Pharms. USA, Inc., 743 F.3d 1359, 1369 (Fed. Cir. 2014).

116 Id.

117 Id.

118 Id. 
Doctrinal Structure of Enablement - DRAFT

Jason Rantanen

$8 / 9 / 16$

is not enabled; rather, the challenger is identifying other targets that the specification fails to enable. Take, for example, Automotive Technologies $v$. $B M W$. There, the challenger articulated the targets as being both mechanical side impact sensors and electronic side impact sensors. ${ }^{119}$ The Federal Circuit agreed that the latter were not enabled, and thus the claim was invalid.

Numerous enablement cases involve these types of multiple-target challenges. ${ }^{120}$ Sometimes, as in In re Wright, the court agrees, implicitly or otherwise, with the acceptability of the multiple targets; other times, as in Edwards Lifesciences v. CoreValve, it does not. ${ }^{121}$

When the court accepts the articulation of multiple targets, all of those targets must be enabled. In other words, enablement of a single embodiment does not necessarily overcome the enablement challenge when there are multiple targets to aim for. But this requirement only applies when the court accepts the articulation of multiple targets.

Durel Corp. v. Osram, ${ }^{122}$ provides an excellent example of the difference between requiring that each target be enabled and requiring that any given target be enabled in only one way. There, the court discussed both types of enablement challenges. First, it considered the argument that the patent failed to enable multiple ways to make each of the different claimed metal oxide coatings:

We put to rest, however, Sylvania's argument that the patent is not enabled because the inventors failed to prepare coatings from each of the precursors suggested in the specification. If the disclosure enables a person of ordinary skill in the art to make a particular metal oxide coating from at least one of the suggested precursors, the enablement requirement for that oxide coating is satisfied. See Johns Hopkins Univ. v. CellPro, Inc., 152 F.3d 1342, 1361, 47 USPQ2d 1705, 1719 (Fed. Cir. 1998) (stating that the enablement requirement is met if the description enables any mode of making and using the invention). The court's statement that use of some metal precursors would require undue experimentation, even if true, would therefore not be fatal to the validity of the claim if the patent specification enabled the preparation of the particular

119 Auto. Techs. Int'l, Inc. v. BMW of N. Am., Inc., 501 F.3d 1274, 1282 (Fed. Cir. 2007). 120 See, e.g., In re Vaeck, 947 F.2d 488 (Fed. Cir. 1991), In re Wright, 999 F.2d 1557 (Fed. Cir. 1993), AK Steel Corp. v. Sollac, 344 F.3d 1234 (Fed. Cir. 2003), MagSil Corp. v. Hitachi Glob. Storage Techs., Inc., 687 F.3d 1377 (Fed. Cir. 2012), Liebel-Flarsheim Co. v. Medrad, Inc., 481 F.3d 1371 (Fed. Cir. 2007) (holding that both claimed strains of cyanobacteria had to be enabled by the disclosure); Sitrick v. Dreamworks, LLC, 516 F.3d 993 (Fed. Cir. 2008) (holding that patent must enable both embodiments of claim to be valid).

${ }^{121}$ Edwards Lifesciences AG v. CoreValve, Inc., 699 F.3d 1305, 1309 (Fed. Cir. 2012).

122 Durel Corp. v. Osram Sylvania, Inc., 256 F.3d 1298, 1306-07 (Fed. Cir. 2001). 
metal oxide coating asserted to be non-enabled from another precursor of that metal. For example, if the patent specification enabled a person of ordinary skill in the art to make the claimed titanium dioxide coating from a titanium tetrachloride precursor, it would be irrelevant for purposes of validity if the patent specification did not enable its preparation from a titanium isopropoxide precursor. ${ }^{123}$

It then discussed the possible argument that each metal oxide coating within the scope of the claim needed to be enabled:

\begin{abstract}
Although Sylvania's arguments with respect to precursors are off the mark, Sylvania could still have succeeded in its enablement defense if it had proved that the disclosure does not enable someone of ordinary skill in the art to make oxide coatings within the full scope of the claims. We cannot decide this question without specific factual findings. ${ }^{124}$
\end{abstract}

Put simply, the one mode/full scope rule boils down to the simple principle that for any given target, at least one way of making and using it must be taught; but at least one way of making and using every target must be taught (or, at least, must not require a PHOSITA to engage in undue experimentation to make and use). ${ }^{125}$

Ultimately, then, the court's acceptance of a given target articulation plays a determinative role in the outcome of the enablement challenge. If a court agrees that there are multiple targets, each of which must be enabled, then each of those targets must be enabled. On the other hand, if the court frames the issue as enablement of a single target, then only that one target must be enabled.

\footnotetext{
123 Id. at 1308 .

${ }^{124} \mathrm{Id}$.

125 Kevin Saulsbury's instincts in Pioneers versus Improvers were thus correct when he suggested resolving the apparent split by adopting the rule that "the enablement requirement is met if the specification teaches the PHOSITA how to make and use the full scope of the claimed invention, except that alternate methods of making or using the claimed invention need not be enabled." Saulsbury, supra note 5, at 463. Kevin Collins' "identity rule" captures a similar insight. Collins, supra note 15, at 1106 [Enabling AAT]. It is true that alternate methods of making or using the claimed invention need not be enabled when court views the clamed invention as a single target. The key to the analysis, though, is recognizing that where the court views the claimed invention as consisting of multiple targets, a way to making each of those targets must be enabled. Care must be used with Saulsbury's suggested rule, particularly when method or process claims are involved as it is the making and using itself that constitutes the invention-and thus the question is whether "alternate ways" are distinct targets that each must be enabled or instead different ways of enabling the same target.
} 
Viewing the issue in terms of whether one target or multiple targets have been articulated easily resolves the apparent "split" in the enablement doctrine. Consider those cases cited for the "full scope language," such as Automotive Technologies, Liebel-Flarsheim, and AK Steel. These cases all involved the articulation of multiple targets by the court. In Automotive Technologies, the two targets were the mechanical sensor and the electronic sensor. ${ }^{126}$ In Liebel-Flarsheim, the targets were the fluid injector with a pressure jacket and without.127 And in AK Steel, the targets constituted the range of possible compositions possessing the claimed characteristics. ${ }^{128}$ In each of these decisions, the court articulated the enablement issue in terms involving multiple targets, each of which needed to be enabled.

On the other hand, consider the cases primarily cited for the "one mode" proposition. These cases involve situations where either only a single target was presented to the court or where it implicitly or explicitly recognized only a single target. In the portion of the opinion involving the "any mode" language in Johns Hopkins v. Cellpro, the target for enablement purposes consisted of CD34 antibodies. ${ }^{129}$ CellPro argued that the even if the patent enabled one way to producing those antibodies (the use of the KG-1/KG-1a cell line), "no one ever succeeded in making CD34 antibodies" using alternative methods described in the specification. ${ }^{130}$ Drawing upon the "any mode" language, the court rejected CellPro's contention-a conclusion in line with the court's articulation of just a single target. Or take Edwards $v$. CoreValve, which involved a claim to a "valve prosthesis for implantation in a body channel."131 The challenger argued that the specification only disclosed testing in pigs, not humans, yet the claim was not limited to implantation in pigs. On appeal, the court affirmed the jury's rejection of the non-enablement argument, concluding that the testing in pigs was sufficient to enable the claimed invention. ${ }^{132}$ One reading of the court's opinion is that the court viewed the enablement inquiry as involving just a single target, that of the stent, that was enabled by demonstrating its use in pigs. ${ }^{133}$ An alternative reading is that it did indeed see separate targets that both needed to be enabled, but the testing in pigs was sufficient to also enable the device with respect to humans. ${ }^{134}$ Viewed in this light, the court's approval of the "any

${ }^{126}$ Auto. Techs. Int'l, Inc. v. BMW of N. Am., Inc., 501 F.3d 1274, 1285 (Fed. Cir. 2007). 127 Liebel-Flarsheim Co. v. Medrad, Inc., 481 F.3d 1371, 1380 (Fed. Cir. 2007).

128 AK Steel v. Sollac, 344 F.3d 1234, 1244 (Fed. Cir. 2003).

129 Johns Hopkins Univ. v. CellPro, Inc., 152 F.3d 1342, 1361 (Fed. Cir. 1998).

$130 \mathrm{Id}$.

131 Patent No. 5,411,552, claim 1.

132 Edwards Lifesciences AG v. CoreValve, Inc., 699 F.3d 1305, 1310 (Fed. Cir. 2012).

133 Id. at 1309-10. This can be seen in the court's discussion of a "general rule" that

"when experimentation on human subjects is inappropriate, as in the testing and development of drugs and medical devices, the enablement requirement may be met by animal tests or in vitro data."

${ }^{134}$ Id. at 1310 . As shown by the court's description of the evidence presented at trial including "the established use of porcine valves in humans." 
Doctrinal Structure of Enablement - DRAFT

Jason Rantanen

$8 / 9 / 16$

mode" language was not determinative; rather, what mattered was the court's articulation of the invention. ${ }^{135}$

This single/multiple target principle also explains the "split" in the $19^{\text {th }}$ Century Supreme Court decisions. In Tilghman v. Proctor, the Supreme Court perceived the target for disclosure purposes to involve subjecting "fatty and oil bodies to the action of water at a high temperature and pressure, so as to cause the elements of those bodies to combine with water and thereby obtain at the same time free fat acids and solution of glycerine."136 There, the court articulated only a single target and thus disclosure of only one mode was necessary. On the other hand, where the Court saw multiple targets, such as the Incandescent Lamp Case or Bene v. Jeantet, or even O'Reilly v. Morse, it required more than a single mode to be taught. ${ }^{137}$

Much other enablement doctrine is layered on top of the single/multiple target dynamic. Consider, for example, the proposition that not every detail need be provided in the specification because a person of ordinary skill in the art will bring background knowledge and skill to the problem. ${ }^{138}$ This proposition can operate in both the single and multiple target contexts. In the single target context, the presence of a person of skill in the art extends the extent which a disclosure enables a single target based on a disclosure that omits some details already known in the art. In the multiple target context, the presence of such a person allows for multiple targets to be enabled by a description of just one, as in Spectra-Physics. ${ }^{139}$ The proposition allowing some-but not undue-experimentation works in a similar way, both extending the extent to which a limited disclosure can enable a single target, as

135 See also Invitrogen v. Clontech, 492 F.3d 1052, 1071 (9th Cir. 2007) (viewing the target for enablement purposes as being "genetically engineered RT without regard for the method used to mutate the genes."). Given this target, the patent needed to enable only one way to achieve the desired mutation.

136 Tilghman v. Proctor, 102 U.S. 707, 729-30 (1880). Although the court follows this with other, more concrete, elements, it ultimately views Tilghman's invention in these relatively simply terms. See id. at 733 (describing Tilghman's discovery as “a process of decomposing fats by mixing them with water, and heating the mixture to a high temperature under a pressure that prevents the formation of steam.")

137 Consolidated Electric Light Co. v. McKeesport Light Co., 159 U.S. 465 (1895). Bene v. Jeantet, 129 U.S. 683, 686 (1889). 0’Reilly v. Morse, 56 U.S. 62, 119-20 (1853). 138 Hybritech, Inc. v. Monoclonal Antibodies, Inc., 802 F.2d 1367 at 1384 (Fed. Cir. 1986) (A patent need not, and preferably omits, what is well known in the art."). 139 Spectra-Physics v. Coherent, Inc., 827 F.2d 1524, 1533 (Fed. Cir. 1987) ("If an invention pertains to an art where the results are predictable... a broad claim can be enabled by disclosure of a single embodiment."); see also AK Steel v. Sollac, 344 F.3d 1234, 1244 (Fed. Cir. 2003) ("That is not to say that the specification itself must necessarily describe how to make and use every possible variant of the claimed invention, for the artisan's knowledge of the prior art and routine experimentation can often fill gaps, interpolate between embodiments, and perhaps even extrapolate beyond the disclosed embodiments, depending upon the predictability of the art."). 
Doctrinal Structure of Enablement - DRAFT

Jason Rantanen

$8 / 9 / 16$

in Streck, ${ }^{140}$ and in allowing a description of one mode to enable more, as in Cephalon v. Watson. ${ }^{141}$

The bottom line is that it's not the choice of the precedent that's so determinative in these enablement cases. Instead, it's how the court views the target or targets that matters. This is important because it suggests that patent doctrine isn't quite a fractured as it has been portrayed-at least, with respect to this issue.

That said, given the importance of target articulation in the enablement analysis, the court should make explicit what it is implicitly doing and recognize the distinction between enablement disputes involving only a single target and those that involve multiple identifiable targets. Doing so will aid in the development of a better understanding of what constitutes a valid target for enablement purposes.

\section{THE CHARACTERISTICS OF A VALID TARGET}

If enablement determinations often come down to the acceptability of given targets, the important question then becomes "how are targets determined for purposes of enablement?"

This is, unfortunately, a challenging question to answer at present due to the implicit nature of target articulation. There is no formal statement in the law of enablement that requires the target to be defined, and while Federal Circuit judges usually do it in the pages of the opinion itself, they don't say what it is that they're doing. Nevertheless, we have figured out a few things when it comes to what can and can't be a target for purposes of the enablement analysis. Kevin Collins and Bernard Chao, among others, have worked out some key attributes.

First, foreseeability. As Kevin Collins observed several years ago, the enablement case law seems to inherently contain a safe harbor for afterarising technologies that were unforeseeable at the time of filing, in that such technologies need not be enabled. ${ }^{142}$ This idea makes a lot of sense: we can't expect inventors to ensure that they have enabled targets that they couldn't even have imagined at the time of filing. But we can expect inventors to enable targets that they could foresee. The "nascent technology" discussion in Chiron v. Genentech illustrates this point. ${ }^{143}$ Foreseeability does not require the present existence of the technology: indeed, something can potentially be a

140 Streck, Inc. v. Research \& Diagnostic Sys., 665 F.3d 1269, 1290-91 (Fed. Cir. 2012) (concluding that accused infringer failed to produce evidence that undue experimentation was required to make a "true reticulocyte integrated control"). 141 Cephalon, Inc. v. Watson Pharms., Inc., 707 F.3d 1330, 1339 (Fed. Cir. 2013).

142 Kevin Emerson Collins, Enabling After-Arising Technology, 34 J. CoRP. L. 1083 (2009).

143 Chiron Corp. v. Genentech, Inc., 363 F.3d 1247, 1257 (Fed. Cir. 2004). 
target even if it wasn't actually in existence at the time. As long as a given target was foreseeable at the time of the invention, however, it may be valid. ${ }^{144}$

Relatedly, as Bernard Chao observed, if the specification identifies something, it's fair game to be used as a target. ${ }^{145}$ Automotive Techs provides an example of this type of reasoning. ${ }^{146}$ In addition, if if the patentee itself contends that particular embodiments of the patent rise to the level of independently patentable inventions, those distinctions can lead to distinct targets. ${ }^{147}$

Second, ranges. If a patent claim includes a range, courts will tend to include every iteration within the range as a target for enablement purposes. "[W]hen a range is claimed, there must be reasonable enablement of the scope of the range."148 The effect when ranges are claimed is that each variation within the range constitutes a separate target that must be enabled. Of course, a fair amount of interpolation and extrapolation is permitted. ${ }^{149}$

MagSil v. Hitachi offers just one of many examples in the range context. 150 That case involved an open-ended range: "a change in resistance of at least $10 \%$," with a patent owner who advocated for a construction of this claim term that encompassed changes of $100 \%$ or more. ${ }^{151}$ This presented the scope of the enablement issue: given the disclosure in the specification, could a person of skill in the art at the time of the patent make the claimed invention with ranges of $20 \%, 120 \%, 600 \%$ or even $1000 \%$ ? ${ }^{152}$ These, then set out the targets-targets that the disclosure did not come close to enabling. ${ }^{153}$

144 Another case that can be read as a foreseeable target case is Monsanto v. Syngenta Seeds, Inc. 503 F.3d 1352, 1361 (Fed. Cir. 2007) (requiring enablement of the invention in both monocotyledon and dicotyledon plants). See also Promega v. Life Technologies, 773 F.3d 1338, 1349 (Fed. Cir. 2014) (concluding that thousands of undisclosed embodiments needed to be enabled for the full scope of the claims to be enabled).

145 Chao, supra note 13 , at 14 ("Given that the claims were plainly drafted with the intent to cover these 'other' embodiments, it seems fair to insure that the patent specification actually teaches the public to make and use them.").

${ }^{146}$ Automotive Technologies at 20. But see Spectra-Physics v. Coherent, Inc., 827 F.2d 1524, 1533 (Fed. Cir. 1987).

147 See Promega, 773 F.3d at 1348.

148 AK Steel Corp. v. Sollac, 344 F.3d 1234, 1244 (Fed. Cir. 2003).

149 Id. ("That is not to say that the specification itself must necessarily describe how to make and use every possible variant of the claimed invention, for the artisan's

knowledge of the prior art and routine experimentation can often fill gaps, interpolate between embodiments, and perhaps even extrapolate beyond the disclosed embodiments, depending upon the predictability of the art.").

150 MagSil Corp. v. Hitachi Glob. Storage Techs., 687 F.3d 1337 (Fed. Cir. 2012).

151 Id. at 1381-82.

152 Id. at 1382.

153 Id. at 1382 ("The named inventors were not able to achieve even a $20 \%$ change a year after filing the application in 1995, and 605\% junctions were not achieved until 2008."). Note that "open ended claims are not inherently improper; as for all claims, their appropriateness depends on the particular facts of the invention, the disclosure, 
Multiple targets also seem to arise when claims are described in "genus" terms. Unfortunately, this terminology is prone to creating confusion due to the different meanings it can carry. For many people, the biological classification concept of "genus" is deeply ingrained, such that the term refers to a set of constituent "species." A species' presence in one genus precludes its simultaneous presence in another genus.

But a genus may also be viewed as a collection of common characteristics. From this perspective, ostriches and pteranodons are both species within the genus "animals with wings," even as ostrichs are simultaneously a member of the genus of "flightless birds" and pteranodons are not.

When a genus is viewed as being made up of identifiable constituents, those individual "species" will tend to present individual targets, such that each must be enabled. ${ }^{154}$ On the other hand, where a genus is viewed as a set of common characteristics, it will may look more like a single target. Unfortunately, choosing between the two views of a genus-style claim can sometimes presents a fundamental problem of enablement law, and it is here-at the point of genus-as-species versus genus-as-common characteristic - that sometimes written description may be a better tool for analyzing claim scope relative to the disclosure. ${ }^{155}$

Another attribute of targets is that they often seem to occur at the point where the claim uses results-oriented language that lacks a necessary structural counterpart, particularly at the very point where the inventor asserts an improvement over the existing state of the art. ${ }^{156}$ In these situations, alternative structures that provide that function can sometimes be targets. This is especially true when the results-oriented language is at the point of novelty. The idea here is that defining the target for purposes of the enablement analysis necessarily involves thinking about what the contribution is relative to the prior art.

Much of this ties into claim construction, both in the formal literalmeaning sense and in the more general sense of defining the invention itself. The literal meaning of the claim elements themselves can result in

and the prior art. They may be supported if there is an inherent, albeit not precisely known, upper limit and the specification enables one of skill in the art to approach that limit." Scripps Clinic \& Research Found. v. Genetech, Inc., 927 F.2d 1565, 1572 (Fed. Cir. 1991).

154 See, e.g., In re Vaeck, 947 F.2d 488, 496 (Fed. Cir. 1991) ("This means that the disclosure must adequately guide the art worker to determine, without undue experimentation, which species among all those encompassed by the claimed genus possess the disclosed utility."); Wyeth \& Cordis Corp. v. Abbott Labs., 720 F.3d 1380, 1386 (Fed. Cir. 2013); Promega v. Life Technologies Corp., 773 F.3d 1338, 1348-50 (Fed. Cir. 2014).

155 See Jeffrey Lefstin, The Limits of Enablement. 156 See Auto. Techs. Int'l, Inc. v. BMW of N. Am., Inc., 501 F.3d 1274, 1284-85 (Fed. Cir. 2007) ("Electronic side impact sensors are not just another known species of a genus consisting of sensors, but are a distinctly different sensor compared with the wellenabled mechanical side impact sensor that is fully discussed in the specification."). 
Doctrinal Structure of Enablement - DRAFT

Jason Rantanen

$8 / 9 / 16$

interpretations that compel the recognition of multiple targets. Liebel-

Flarsheim, Automotive Technologies, and Magsil v. Hitachi provide examples where the interpretation of the claim language itself resulted in the articulation of multiple targets. ${ }^{157}$ Sometimes, though, the court engages in claim construction that focuses less on arriving at the literal meaning of the claim terms and more on articulating the invention as a whole. Edwards Lifescience offers an example of this type of claim construction, where the court describes what the invention is not by reference to its constituent parts, but by a more general articulation. ${ }^{158}$ That the court is taking different approaches to claim construction in these cases is particularly interesting in light of recent scholarship highlighting the perils of treating claim construction as if it is simply the process of divining the literal meaning of claims ${ }^{159}$ and that observing that in the context of $\S 101$ patent eligible subject matter analyses, courts are approaching claim interpretation in a way that focuses less on the literal meaning of words and more on what the invention is as a whole. ${ }^{160}$

And finally, how the patent challenger has articulated the challenge matters. If the challenger defines just a single target, that's almost certainly how the court will as well. Similarly, the patent owner itself may decline to challenge the articulation of multiple targets, thus leading the court to analyze the enablement of the separate targets. ${ }^{161}$

\section{CONCLUSION}

157 See Liebel-Flarsheim Co. v. Medrad, Inc., 481 F.3d 1371 (Fed. Cir. 2007) (claims were interpreted to include fluid injectors with and without pressure jackets); Auto. Techs. 501 F.3d at 1284 (claim element interpreted as being both mechanical and electronic sensors); MagSil, 687 F.3d 1377, 1381 (claim term interpreted as an openended range).

158 Edwards Lifesciences AG v. CoreValve, Inc., 699 F.3d 1305, 1308-1310 (Fed. Cir. 2012) ("The '552 patent is directed to a collapsible stent that carries a valve for insertion into the heart by balloon catheter."). Indeed, in Edwards, the court never recited the claims at all in connection with the enablement analysis (the recitation of claim 1 actually comes later, in the discussion of infringement), let alone engage in what we today usually recognize as claim construction. See also Invitrogen, 429 F.3d 1052, 1070 (following a similar approach).

159 See John F. Duffy, Counterproductive Notice in Literalistic versus Peripheral Claiming, BosTON U. L. REV. (forthcoming); Oskar Liivak, Rescuing the Invention from the Cult of the Claim, 42 SETON HALL L. REV. 1 (2012).

160 See Andres Sawicki, The Central Claiming Revolution [draft article]. 161 See, e.g., Cephalon v. Watson, 707 F.3d 1330, 1337 (Fed. Cir. 2013) (patent owner did not appeal the "single compound effervescent agent" construction); Sitrick $v$. Dreamworks, LLC, 516 F.3d 993, 999 (Fed. Cir. 2008) (patent owner did not appeal district court's construction of the claims as including both video games and movies; both thus needed to be enabled). 
Ultimately, all of these very different approaches can be understood, and their conceptual underpinnings harmonized, by appreciating two critical points. First, that enablement issues arise only in the context of a challenge to the enablement of a patent claim; and second, that the critical part of that challenge is the articulation of what the target for the enablement inquiry is. This second component is implicit; and yet, it is so important that ultimately, it often determines the outcome of the case. With this understanding in mind, the "full scope" and "any mode" language are easily reconciled: for any given target, one mode suffices. But each and every target must be enabled. 